\title{
Attitudes toward the Effectiveness of Communicative and Educational Language Games and Fun Activities in Teaching and Learning English
}

\author{
Marjan Sobhani \\ English Department, Faculty of Humanities, Islamic Azad University, Shiraz Branch, Iran \\ Mohammad Sadegh Bagheri \\ English Department, Faculty of Humanities, Islamic Azad University, Shiraz Branch, Iran
}

\begin{abstract}
This research intended to investigate the attitudes of learners and teachers about the effectiveness of using games and fun activities regarding learning English. To do so, a modified questionnaire with 25 items was conducted. The participants were 40 students and 40 teachers from one of Shiraz language institutes. The results showed that both learners' and teachers' attitudes were positive toward language games and they considered games as learning lubricants. Also, games and fun activities can help learners to be interested in learning as well.
\end{abstract}

Index Terms - communicative language games, educational language games, fun activities

\section{INTRODUCTION}

Language is defined by Collins dictionary (2000) as a system for the expression of thoughts, feelings, etc., by the application of spoken sounds or conventional symbols. Game means an activity in which the learners play and usually interact with others and is defined as a system of manipulating spoken words to the untrained ear. Language games are identified as play languages. In another sense, language games are not technically artificial languages as much as heuristics for modifying language, like a code. The first group who used the language, just attempted to conceal their conversations from others. It is obvious that all language learners respond differently to language games. Each language game involves a usually simple standard transformation to speech, in order to encode it. Teachers have preferred to minimize competition when they select and describe the games, with winners and losers, and to maximize challenge and competition, where everyone feels inspired to do their best. Games help and encourage many learners in sustaining their interest and work (Wright, Betteridge, \& Buckby, 1984). By conducting games, teachers can create more useful and meaningful situations for understanding the languages. In conducting language games, both teachers and learners have critical roles to make it understandable and applicable.

McCallum (1980) emphasized that games automatically result in student interest, and increase their motivation. Avedon (1971 cited in Deesri, 2000, p. 2) discussed that games cause motivation and make students interested to have positive competition in doing games; moreover, they become excited and try their best to play these games. In other words, games make them motivated and automatically result in learning. Crookal (1990) believed that games have a lot of advantages to decrease anxiety and make them feel better, so they can feel more confident and relaxed, because they feel free and never think about punishment and any bad consequences of wrong answers. Games can be useful for teachers as well in their educational aspects.

Nedomová (2007), Bekiri (2003) and Hong (2002) all mentioned some major areas in using games for teaching grammar to young learners. Nedomová (2007), Rixon (1991), and McCallum (1980) decided about type of language games. Lee (1979) and Rinvolucri (1990) mentioned the best time for applying the games. McCallum (1980) discussed the role of teacher in using games especially for young learners and class organization and participation of the learners. Teacher's preparation and his/her role as a facilitator is argued by Celce-Murcia (1979) and the effectiveness of using games in teaching grammar to young learners was observed by Amato (1988), Gunn and McCallum (2005), Deesri (2000), Celce-Murcia and Hilles (1988). As the games are the natural part of every classroom activity, they are the most suitable and effective activities for young learners.

Nedomová (2007) argued that young learners became bored after 20-30 minutes when they are in the class. Teachers can use instructional or educational games in different language skills in their classes to improve their students' understanding. FAS (2006), Hays (2005), Sitzmann, (2011), Tobias and Fletcher (2011) confirmed that instructional games and simulations can be exciting in classrooms especially when teachers use them in different areas in their teaching. Sindre (2009) stated that educational games, compared to other types of learning materials, could convey new 
concepts to players in a much funnier, communicating and active way. Their use in education can increase students' motivation and skills acquisition. Hirumi, Appelman, Rieber, and Van Eck (2010) found that designing games can be a difficult attempt, and planning educational games has the extra layer of including educational intentions in the design. Rieber, Barbour, Thomas, and Rauscher (2008) mentioned that a game should have an enticing storyline and keep the player motivated by providing the appropriate amount of difficulty to be considered good.

\section{A. Suitable Types of Games}

The games and fun activities should be suitable for the level of the students in the class and with the purpose of reinforcing taught materials to be digestible and understandable for all learners in the class.

\section{B. Suitable Time for Playing Games}

Games should be conducted when all the students are ready, the time when they are distracted and the teacher wants to draw their attention and needs their involvement. Games can be done at the end of the class time or after each part of the lesson to reinforce learning materials. The time that teachers want to motivate their students is the best time to conduct games.

\section{LITERATURE REVIEW}

The review of the studies related to language games indicated that games are one of the most important parts in foreign language teaching and learning in a variety of areas. Barrett (2012) stated that games are for playing, more often than not playing, a game is a social experience; it is enjoyable, and all people enjoy playing games. Play and playing are ways through which we learn, so games can be parts of the normal activity of the classroom. Clyde and Wilkinson (2012) believed that the use of digital games is a new way in handling a class and motivating students by applying simulation because they are different from text or board games, and it is more exciting for learners.

Connolly, Stansfield, and Hainey (2011) mentioned Alternate Reality Games (ARGs), is an innovative way of telling story, and narration by employing multiple media and gaming elements based on participants' actions. In his article, Dickinson (1981) explained different use of methods in involving learners in their second language for the purpose of communication such as games, role-play, and reproductions for better interaction with others. Guillen-Nieto (2012) also stated that besides the value of games, it is important to consider types of games, their procedure for class application, and the result of using these games in the class, He concluded that the video game is an effective learning tool for the teaching. In particular, games had learning effect on both learners' intercultural and cultural knowledge, and their communicative competence for culture.

Larsen (2012) created a new design perspective for game-based learning in which there is no teacher interference is needed and learners can do it by using their computers. Anyaegbu (2012) discussed the integration of Serious Games specifically Mingoville for motivating EFL learners in China. He used this in two different schools and got different results because of the attitudes of teachers and parents toward game- based learning in classrooms.

Arnold (1979) also discussed the role of instructional games in foreign language learning at the intermediate and advanced levels. Games can provide an outline for correct use of language and can create conversation. Yolageldili's invetigation (2011) about the usefullness of games in teaching grammar in turkey demonstrated that Turkish EFL teachers accept that games are effective in learners' better learning bit they do not use games in their class a lot. Sylven and Sundqvist (2012) mentioned that playing digital games like multiplayer online role-playing games (MMORPGs) improve learners' linguistic and cognitive knowledge a lot, which are conducive to L2 learning, because it brings opportunities for L2 input and foster their interactions in the L2.

Sundqvist's research (2009) in vocabulary learning demonstrated that there is a positive correlation between playing digital games and L2 proficiency among learners aged 15-16. The researcher found out that gender also made differences in which boys outperformed girls as well as the frequency of gaming and types of games played. The findings suggested that playing digital games at an early age could be important for L2 acquisition without considering which gender outperforms the other.

Shameem and Tickoo (1999) investigated classroom games to teach communicative skills in English as a second language, allowing students to use communication strategies in English in realistic situations similar to those in which they would use their native language. An introductory section outlines the rationale for the use of games in communicative second language learning, the method used for selecting the tasks and activities presented, and the goals of communicative activities. Subsequent sections detailed activities in five categories: learning communication strategies (asking questions, negotiating, pronunciation); learning content material (guessing words in context, developing reading skills, promoting writing skills, forming speaking skills); learning from one another (enriching vocabulary and productive vocabulary use, imparting and seeking factual information, confirmation and clarification, expressing emotional attitudes); developing skills in discourse (conducting interviews and conversations, cooperative storytelling in verbal and written forms, grammar in discourse), and developing fluency (review and correction, improving fluency with known vocabulary, capitalizing on content, improving speaking skills, working with writing). Information provided about each activity includes targeted class levels, instructional aims, class time, preparation time, materials needed, procedures, caveats and options, references and further reading, and with the help of the teacher. 
Savignon (1973) said that communicative competence, the ability to use a language proficiently in impromptu contacts with native speakers, must be the last objective of language teaching. Drills and repetition of designed expressions do not result in real language use. We should begin giving students chances to use language in unrehearsed, amorphous situations much earlier than we presently do. The emphasis should be on communicative competence then linguistic competence. A research indicated that a group of French students who had been given systematic opportunities for creative use of French in a variety of unrehearsed settings far outperformed the control group in tests designed to evaluate communicative competence. A cultural context could be simulated to give authenticity to language learning and bring about emotional involvement on the part of the students. Games were a relatively unexploited means for generating spontaneous language contacts. "Maisvousetes ma femme!" was an illustration which met all criteria for a good language game. The main concern of the language teacher must be authenticity in the classroom. Structural exercises and drills were the most effective opportunity for free use of language.

Kimball's and Palmer's paper (1978) described a formal communicative game, which required the students to process other players' utterances for implicit meaning before responding. The game could be adapted for content and difficulty level. Students had to choose between two alternatives on dimensions such as structure and style. Sample games were included as well. Jones (1986) outlined in his booklet the instructions for 10 games that have proved to be effective in English for speakers of other languages (ESOL) courses. The games presented are divided into four categories: dialog games, vocabulary games, structure focus, and pronunciation practice. "The Chain Game" called for students to take turns asking each other questions, always repeating the response given by the previous player before posing the question to the next player. The second dialog game allowed students to demonstrate reading comprehension by matching pictures with stories. A vocabulary game called "Is It?" gave students the opportunity to practice a common question-and-answer pattern and simple descriptions. Four structure-focus games were described as "Cooperative Sentences" (which taught sequential sentence order), "What Happened?" (in which students increased reading comprehension by acting out character roles and gain cultural insight as they role-play); "Where Is It?" (It is designed to increase students' comprehension of prepositions); and "Colored Sentences" (in which students learned the proper placement of modifiers in English sentences). "Hearing and Writing", "Say-Show," and "Vowel Bingo"--allowed students to get immediate feedback on their pronunciation accuracy are all pronunciation games.

Generally, beside the value of games in the instructional and learning processes, they are also effective in improving linguistic skills and communicative abilities. Harper (1981) introduced a large number of group activities and games for elementary and intermediate levels based on the purpose, the procedure, and some examples of game, which could also be appropriate in more advanced classes.

\section{ReSEARCH MeTHODOLOGY}

This study intended to investigate the attitudes of learners and teachers toward the effectiveness of games and fun activities for learning English and find ways through which learners' knowledge can be enhanced and reinforced.

\section{A. Participants}

The participants of this study included 40 male and female EFL teachers from one of Shiraz language institutes and 40 male and female EFL learners of teen levels of the same institute.

\section{B. Instrumentation}

A modified questionnaire was designed for both teachers and students in which the first part was about their demographic information and the second part was a Likert scale of 25-item questionnaire (strongly agree (SA), agree (A), neutral (E), disagree (DA), and strongly disagree (SDA)) on the effectiveness of language games and fun activities. The learners' questionnaire was translated into their L1 (Persian) for better understanding of the questions.

\section{Procedure}

The questionnaires were handed to teachers and learners. With their helpful participation, all 80 questionnaires were collected; 40 were related to learners and the rest were for teachers.

\section{DATA ANALYSis}

After data collection was done, the questionnaire was codified based on the motivation of students for using games and fun activities, the effectiveness of using games and fun activities, attitudes of learners and teachers toward these games and fun activities, and the difficulties encountered by teachers and students in using games and fun activities. The Likert scale was also codified in a way each answer got its own score: strongly agree (2), agree (1), neutral (0), and disagree (-1), and strongly disagree (-2).

The researchers selected two methods for analyzing data: $t$-test by using SPSS software and giving percentage for each item. Tables 2 to 9 are attached for clarification of the results in appendix A.

\section{RESULTS AND DisCUSSION}


An independent sample t-test was performed to investigate effectiveness of application of communicative and educational games and fun activities. The result of this test indicated that there is a statistically significant difference between teachers and learners attitude for the application of games and fun activities in classroom to promote learning. (Table 1)

The percentages for each item showed that both teachers and learners are motivated in using games and fun activities in the classroom and they think that games and fun activities are effective in learning a new language. Both groups had positive attitudes toward games and fun activities, however; there were some problems and difficulties in performing games and fun activities. They thought that using games and fun activities can make class more active and energetic in learning new lessons. (See Appendix A, Tables 2-9)

TABLE 1:

INDEPENDENT SAMPLES T-TEST FOR THE EFFECTIVENESS OF GAMES AND FUN ACTIVITIES

\begin{tabular}{|c|c|c|c|c|c|c|c|c|c|}
\hline & \multicolumn{2}{|c|}{$\begin{array}{l}\text { Levene's Test for Equality } \\
\text { of Variances }\end{array}$} & \multicolumn{7}{|c|}{ t-test for Equality of Means } \\
\hline & \multirow[b]{2}{*}{$\mathrm{F}$} & \multirow[b]{2}{*}{ Sig. } & \multirow[b]{2}{*}{$\mathrm{T}$} & \multirow[b]{2}{*}{ Df } & \multirow{2}{*}{$\begin{array}{l}\text { Sig. (2- } \\
\text { tailed) }\end{array}$} & \multirow{2}{*}{$\begin{array}{l}\text { Mean } \\
\text { Difference }\end{array}$} & \multirow{2}{*}{$\begin{array}{l}\text { Std. Error } \\
\text { Difference }\end{array}$} & \multicolumn{2}{|c|}{$\begin{array}{l}95 \% \text { Confidence Interval of the } \\
\text { Difference }\end{array}$} \\
\hline & & & & & & & & Lower & Upper \\
\hline $\begin{array}{l}\text { score Equal variances } \\
\text { assumed }\end{array}$ & 4.149 & .045 & 3.059 & 78 & .003 & 4.37500 & 1.43003 & 1.52803 & 7.22197 \\
\hline $\begin{array}{l}\text { Equal variances not } \\
\text { assumed }\end{array}$ & & & 3.059 & 73.313 & .003 & 4.37500 & 1.43003 & 1.52516 & 7.22484 \\
\hline
\end{tabular}

\section{CONCLUSION}

It is obvious that using traditional methods of teaching cannot be sufficient these days and learners need to have abilities for communication, they need to be confident enough to communicate in real life context and they should not memorize or duplicate some rules. To do so, teachers should apply different methods beside traditional method of language teaching to motivate learners for meaningful learning and this goal is achievable if teachers use games and fun activities, which are more attracting and interesting for learners. These methods can activate their minds to learn through games and remember learned materials better, and then use them in their communication. Teachers can facilitate their teaching by adding some educational and communicative games and fun activities in teaching to motivate their learners and make learning more understandable for them.

APPENDiX A. TABLES 2-9

TABLE 2:

MOTIVATION OF TEACHERS FOR USING GAMES AND FUN ACTIVITIES IN THE CLASS

\begin{tabular}{|c|c|c|c|c|c|}
\hline Questions & $\mathbf{S A}$ & $\mathbf{A}$ & $\mathbf{E}$ & DA & SDA \\
\hline 1. When I use games, my students learn better. & 57.5 & 37.5 & 5 & - & - \\
\hline 6. Games make lessons more interesting. & 57.5 & 40 & - & 2.5 & - \\
\hline 12. I like to give my students more time to play. & 7.5 & 57.5 & 20 & 12.5 & 2.5 \\
\hline 18. I like my students to sing songs aloud in class. & 22.5 & 37.5 & 20 & 17.5 & 2.5 \\
\hline 21. I like my students to choose the games/ activities themselves not me. & 2.5 & 17.5 & 35 & 32.5 & 12.5 \\
\hline 24. I prefer to start the lesson with fun activities for students to give them more energy. & 32.5 & 32.5 & 12.5 & 7.5 & 2.5 \\
\hline
\end{tabular}

(Figures in percentage)

TABLE 3:

THE EFFECTIVENESS OF USING GAMES AND FUN ACTIVITIES FROM TEACHERS' PERSPECTIVE (FIGURES IN PERCENTAGE)

\begin{tabular}{|c|c|c|c|c|c|}
\hline Questions & $\mathbf{S A}$ & $\mathbf{A}$ & $\mathbf{E}$ & DA & SDA \\
\hline 2. I like to conduct games just for fun not learning. & - & 10 & 7.5 & 60 & 45 \\
\hline 3. I like to use games for teaching new things. & 17.5 & 72.5 & 7.5 & 2.5 & - \\
\hline 4. When students play games, they can speak English more. & 20 & 40 & 40 & - & - \\
\hline 5. I don't like to give marks when my students play games. & 25 & 30 & 25 & 20 & - \\
\hline 16. I like to play games during the lesson not after that. & 2.5 & 35 & 37.5 & 22.5 & 2.5 \\
\hline 19. I like to compare my students in games. & 2.5 & 35 & 25 & 25 & 12.5 \\
\hline 22. I prefer my students to play games other than educational games. & - & 5 & 12.5 & 50 & 32.5 \\
\hline 23. I like to play games when I am tired and cannot teach my students something. & - & 12.5 & 20 & 45 & 22.5 \\
\hline
\end{tabular}

TABLE 4:

ATTITUDES OF TEACHERS TOWARD GAMES AND FUN ACTIVITIES (FIGURES IN PERCENTAGE)

\begin{tabular}{|c|c|c|c|c|c|}
\hline Questions & $\mathbf{S A}$ & $\mathbf{A}$ & $\mathbf{E}$ & DA & SDA \\
\hline $\begin{array}{l}\text { 9. I don't like fun activities because they can't help learners learn anything more than they } \\
\text { know. }\end{array}$ & - & 2.5 & 7.5 & 47.5 & 42.5 \\
\hline 13. Students are not aware of the purposes of playing games. & 12.5 & 37.5 & 37.5 & 12.5 & - \\
\hline 14. Some games are hard and confusing for students to play. & 2.5 & 50 & 27.5 & 20 & - \\
\hline
\end{tabular}


TABLE 5:

DIFFICULTIES THAT ARE ENCOUNTERED BY TEACHERS IN USING GAMES AND FUN ACTIVITIES (FIGURES IN PERCENTAGE)

\begin{tabular}{|c|c|c|c|c|c|}
\hline Questions & $\mathbf{S A}$ & $\mathbf{A}$ & $\mathbf{E}$ & DA & SDA \\
\hline 7. My class environment is not suitable enough for playing games. & - & 27.5 & 25 & 45 & 2.5 \\
\hline 8. When students play games, they make a lot of noise. & 22.5 & 30 & 27.5 & 17.5 & 2.5 \\
\hline 10. When students play games, I can't understand whether they learn or not. & - & 12.5 & 10 & 55 & 22.5 \\
\hline 11. There is a lack of materials for good language games in the textbooks. & 17.5 & 37.5 & 30 & 12.5 & 2.5 \\
\hline 15. Some students are too shy to speak English in front of their classmates, even in game sessions. & 12.5 & 57.5 & 17.5 & 10 & 2.5 \\
\hline 18. I like my students to sing songs aloud in class. & 22.5 & 37.5 & 20 & 17.5 & 2.5 \\
\hline 20. I prefer cooperation in my class during using games. & 32.5 & 62.5 & - & 2.5 & 2.5 \\
\hline 25. Some games are not practical and suitable enough for students to play. & 12.5 & 67.5 & 12.5 & 7.5 & - \\
\hline
\end{tabular}

TABLE 6:

MOTIVATION OF LEARNERS FOR USING GAMES AND FUN ACTIVITIES IN THE CLASS

\begin{tabular}{|c|c|c|c|c|c|}
\hline Questions & $\mathbf{S A}$ & $\mathbf{A}$ & $\mathbf{E}$ & DA & SDA \\
\hline 1. When my teacher uses games, I learn better. & 47.5 & 42.5 & 7.5 & 2.5 & - \\
\hline 6. Games make lessons more interesting. & 60 & 27.5 & 7.5 & 5 & - \\
\hline 12. I like my teacher to give us more time to play. & 25 & 17.5 & 27.5 & 17.5 & 12.5 \\
\hline 18. I like to sing songs aloud in class. & 17.5 & 12.5 & 20 & 30 & 20 \\
\hline 21. I like to choose the games/ activities myself not my teacher. & 17.5 & 12.5 & 32.5 & 22.5 & 15 \\
\hline 24. I prefer my teacher to start the lesson with fun activities for us to give us more energy. & 62.5 & 20 & 10 & 5 & 2.5 \\
\hline
\end{tabular}

(Figures in percentage)

TABLE 7:

THE EFFECTIVENESS OF USING GAMES AND FUN ACTIVITIES FROM LEARNERS’ PERSPECTIVE (FIGURES IN PERCENTAGE)

\begin{tabular}{|c|c|c|c|c|c|}
\hline Questions & $\mathbf{S A}$ & $\mathbf{A}$ & $\mathbf{E}$ & DA & SDA \\
\hline 2. I like to play games just for fun not learning. & 2.5 & 5 & 10 & 12.5 & 70 \\
\hline 3. I like my teacher to use games for teaching new things. & 40 & 27.5 & 22.5 & 10 & - \\
\hline 4. When we play games, we can speak English more. & 40 & 27.5 & 17.5 & 10 & 5 \\
\hline 5. I don't like my teacher to give marks when I play games. & 22.5 & 15 & 25 & 12.5 & 25 \\
\hline 16. I like to play games during the lesson not after that. & 25 & 17.5 & 17.5 & 20 & 20 \\
\hline 19. I like my teacher to compare us in games. & 30 & 7.5 & 12.5 & 20 & 30 \\
\hline 22. I prefer my teacher to conduct games other than educational games. & 17.5 & 15 & 15 & 17.5 & 35 \\
\hline 23. I like to play games when I am tired and cannot listen to my teacher. & 32.5 & 15 & 15 & 22.5 & 15 \\
\hline
\end{tabular}

TABLE 8:

ATTITUDES OF LEARNERS TOWARD GAMES AND FUN ACTIVITIES (FIGURES IN PERCENTAGE)

\begin{tabular}{|c|c|c|c|c|c|}
\hline Questions & SA & $\mathbf{A}$ & $\mathbf{E}$ & DA & SDA \\
\hline 9. I don't like fun activities because they can't help me learn anything more than I know. & 5 & 5 & 27.5 & 17.5 & 45 \\
\hline 13. We are not aware of the purposes of playing games. & 10 & 5 & 30 & 30 & 25 \\
\hline 14. Some games are hard and confusing for me to play. & 2.5 & 17.5 & 20 & 22.5 & 37.5 \\
\hline
\end{tabular}

TABLE 9:

DIFFICULTIES THAT ARE ENCOUNTERED BY LEARNERS IN USING GAMES AND FUN ACTIVITIES (FIGURES IN PERCENTAGE)

\begin{tabular}{|c|c|c|c|c|c|}
\hline Questions & SA & A & $\mathbf{E}$ & DA & SDA \\
\hline 7. My class environment is not suitable enough for playing games. & 25 & 15 & 40 & 5 & 17.5 \\
\hline 8. When we play games, my classmates make a lot of noise. & 27.5 & 17.5 & 35 & 7.5 & 12.5 \\
\hline 10. When we play games, my teachers can't understand whether we learn or not. & 12.5 & 7.5 & 37.5 & 22.5 & 20 \\
\hline 11. There is a lack of materials for good language games in the textbooks. & 20 & 20 & 27.5 & 25 & 7.5 \\
\hline 15. I am too shy to speak English in front of my classmates, even in game sessions. & 2.5 & 15 & 17.5 & 12.5 & 52.5 \\
\hline 18. I like to sing songs aloud in class. & 17.5 & 12.5 & 20 & 27.5 & 20 \\
\hline 20. My teacher prefers cooperation during using games. & 32.5 & 17.5 & 32.5 & 10 & 7.5 \\
\hline 25. Some games are not practical and suitable enough for us to play. & 17.5 & 5 & 47.5 & 10 & 20 \\
\hline
\end{tabular}

APPENDIX B. QUESTIONNAIRES

Teachers' Questionnaire
1. Age:
2. Gender:
3. Degree of education:

A) Please mark the choice that you think is right.

SA $=$ Strongly Agree $A=$ Agree $E=$ Neutral $\square D=$ Disagreen SDA= Strongly Disagree 


\begin{tabular}{|c|c|c|c|c|c|}
\hline Items & SA & $\overline{\mathbf{A}}$ & $\mathbf{E}$ & $\mathbf{D}$ & SDA \\
\hline \multicolumn{6}{|l|}{ 1. When I use games, my students learn better. } \\
\hline \multicolumn{6}{|l|}{ 2. I like to conduct games just for fun not learning. } \\
\hline \multicolumn{6}{|l|}{ 3. I like to use games for teaching new things. } \\
\hline \multicolumn{6}{|l|}{ 4. When students play games, they can speak English more. } \\
\hline \multicolumn{6}{|l|}{ 5. I don't like to give marks when my students play games. } \\
\hline \multicolumn{6}{|l|}{ 6. Games make lessons more interesting. } \\
\hline \multicolumn{6}{|l|}{ 7. My class environment is not suitable enough for playing games. } \\
\hline \multicolumn{6}{|l|}{ 8. When students play games, they make a lot of noise. } \\
\hline \multicolumn{6}{|l|}{$\begin{array}{l}\text { 9. I don't like fun activities because they can't help learners learn anything more than they } \\
\text { know. }\end{array}$} \\
\hline \multicolumn{6}{|l|}{ 10. When students play games, I can't understand whether they learn or not. } \\
\hline \multicolumn{6}{|l|}{ 11. There is a lack of materials for good language games in the textbooks. } \\
\hline \multicolumn{6}{|l|}{ 12. I like to give my students more time to play. } \\
\hline \multicolumn{6}{|l|}{ 13. Students are not aware of the purposes of playing games. } \\
\hline \multicolumn{6}{|l|}{ 14. Some games are hard and confusing for students to play. } \\
\hline \multicolumn{6}{|l|}{$\begin{array}{l}\text { 15. Some students are too shy to speak English in front of their classmates, even in game } \\
\text { sessions. }\end{array}$} \\
\hline \multicolumn{6}{|l|}{ 16. I like to play games during the lesson not after that. } \\
\hline \multicolumn{6}{|l|}{$\begin{array}{l}\text { 17. Sometimes the large number of students in each class makes problems for conducting } \\
\text { games. }\end{array}$} \\
\hline \multicolumn{6}{|l|}{ 18. I like my students to sing songs aloud in class. } \\
\hline \multicolumn{6}{|l|}{ 19. I like to compare my students in games. } \\
\hline \multirow{2}{*}{\multicolumn{6}{|c|}{ 20. I prefer cooperation in my class during using games. }} \\
\hline \multicolumn{2}{|l|}{ 21. I like my students to choose the games/ activities themselves not me. } & & & & \\
\hline \multicolumn{6}{|l|}{ 22. I prefer my students to play games other than educational games. } \\
\hline \multicolumn{6}{|l|}{ 23. I like to play games when I am tired and cannot teach my students something. } \\
\hline \multirow{2}{*}{\multicolumn{6}{|c|}{ 24. I prefer to start the lesson with fun activities for students to give them more energy. }} \\
\hline 25. Some games are not practical and suitable enough for students to play. & & & & & \\
\hline
\end{tabular}

\section{Learners' questionnaire}

1- Age

2- gender

3- level

B) Please mark the choice that you think is right.

\section{SA= Strongly Agreen A= Agree E= Neutral $\mathrm{ED}=$ Disagree $\mathrm{SDA}=$ Strongly Disagree}

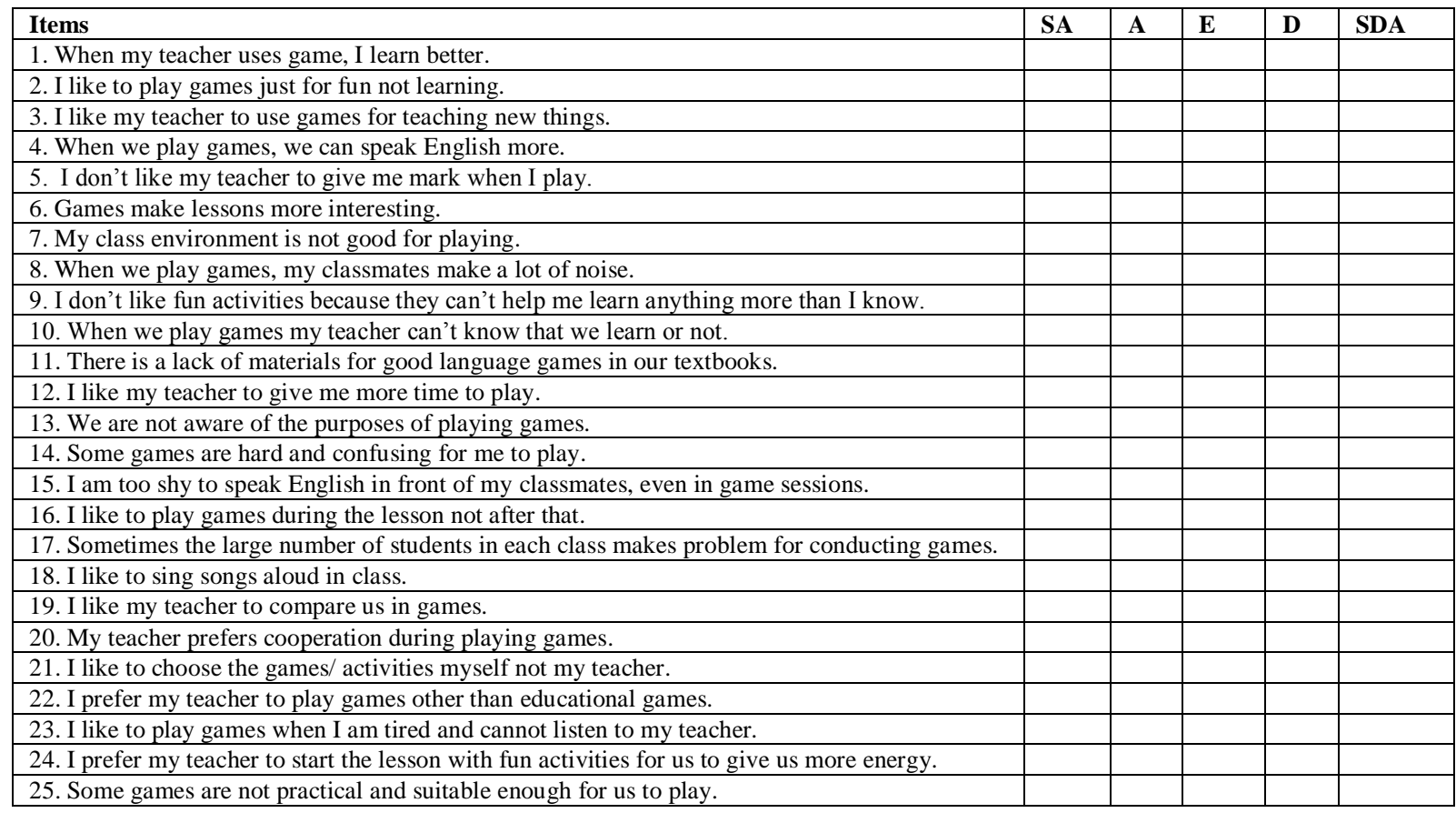

\section{REFERENCES}

[1] Amato, P., \& Amato, A. R. (1988). Making it happen. New York: London.

[2] Anyaegbu, R. (2012). Serious game motivation in an EFL classroom in Chinese primary school. Turkish Online Journal of Educational Technology- TOJET, 11 (1), 154-164. 
[3] Arnold, R. A. (1979). The function of language games in the classroom. English Language Teaching Journal, 33 (3), $205-207$.

[4] Avedon, E.M. (1971)." The structural elements of games". In Avedon, E.M and Sutton Smith, B. (Eds), The study of games (pp419-426). New York: John Wiley and Sons, Inc.

[5] Barrett, K. (2012). "Yes! we are playing a game, and it's going to be fun!". Mathematics Teaching, 23(1), 15-16.

[6] Bekiri, R. (2003). Playing with questions: A game for young learners. The Internet TESL Journal. Retrieved February 25, 2013 from http://www. iteslj.org/Lessons/Bekiri- QuestionGame/.

[7] Celce-Murcia, M., \& Hilles, S. (1988). Techniques and resources in teaching grammar. Oxford: Oxford University Press.

[8] Celce-Murcia, M, \& McIntosh, L. (Eds.). (1979). Teaching English as a second or foreign language (pp.54-55). NewYork: Newbury House.

[9] Clyde,J., \& Wilkinson, G. R. (2012). More than a game. Teaching in the gamic mode: Disciplinary knowledge, digital literacy, and collaboration. History Teacher, 45 (1), 45-66.

[10] Collins English dictionary ( $5^{\text {th }}$ ed.). (2000). HarperCollins Publishers: Glasgow.

[11] Connolly, T. M., Stansfield, M., \& Hainey, T. (2011). An alternate reality game for language learning: Arguing for multilingual motivation. Computers \& Education, 57 (1), 1389-1415.

[12] Crookal, D. (Ed.). (1990). Simulation, gaming, and language learning. New York: Newbury House.

[13] Deesri, A. (2002). Games in the ESL and EFL class. The Internet TESL Journal. Retrieved June 27, 2013, from http://www.iteslj.org/Techniques/Deesri-Games.html.

[14] Dickinson, L. (1981). 'Have You Got Mr. Bun the Baker?' Problems and solutions in the use of games, role play, and simulations. English Language Teaching Journal, 35 (4), 381-384.

[15] Federation of American Scientists (FAS). (2006). Summit on educational games: Harnessing the power of video games for learning. Washington, DC: Author.

[16] Guillen-Nieto, V. (2012). Serious games and learning effectiveness: The case of "It's a Deal!". Computers \& Education, 58 (1), 435-448.

[17] Gunn, C., \& McCallum, A. (2005). Climbing grammar mountain: An interactive learning experience. English Teaching Forum, $43,38-41$.

[18] Harper, S. N. (1981). Game-like activities and the teaching of foreign languages. Albion, MI: Great Lakes Colleges Association Foreign Languages Conference.

[19] Hays, R. T. (2005). The effectiveness of instructional games: A literature review and discussion Orlando, FL: Naval Air Warfare Center Training Systems Division.

[20] Hirumi, A., Appelman, B., Rieber, L.P., \& Van Eck, R. (2010). Preparing instructional designers for game-based learning: Part 2. Tech Trends, 54(4), 19-27.

[21] Hong, L. (2002). Using games in teaching English to young learners. The Internet TESL Journal. Retrieved June 27, 2013, from http://www.iteslj.org/Lessons/Lin- Using Games.html.

[22] Jones, F. (1986). My 10 favorite ESOL teaching games. Topeka: Sun Belt Literacy Bookstore.

[23] Kimball, M. C., \& Palmer, A. S. (1978). The dialog game: A prototypical activity for providing proper intake in formal instruction. TESOL Quarterly, 12 (1), 17-29.

[24] Larsen, L. J. (2012). A new design approach to game-based learning. Journal of Interactive Learning Research, 23 (4), 313 323.

[25] Lee, W. R. (1979). Language teaching games and contests. Oxford: Oxford University Press.

[26] McCallum, G. P. (1980). 101 word games: For students of English as a second or foreign language. Oxford: Oxford University Press.

[27] Nedomová, A. (2007). Teaching grammar to young learners. Unpublished master thesis, Masaryk University, Czech Republic. Retrieved from February 25, 2013, http://www.is.muni.cz/th/44537/pedf_b/bachelor_thesis.pdf.

[28] Rieber, L.P., Barbour, M.K., Thomas, G.B., \& Rauscher, D. (2008). Learning by designing games: Homemade power point games. In C. T. Miller (Ed.), Games: Their purposes and potential in education (pp. 23-42).New York: Springer.

[29] Rinvolucri, M. (1990). Grammar games: Cognitive, affective and drama activities for EFL students. Cambridge: Cambridge University Press.

[30] Rixon, S. (1991). How to use games in language teaching (Ed.). Hong Kong: Modern English.

[31] Savignon, S. J. (1973). Other peoples' languages: A game everyone can play. Indianapolis, Indiana: Indiana Foreign Language Teachers' Association fall meeting .

[32] Shameem, N. E., \& Tickoo, M. E. (1999). New ways in using communicative games in language teaching. New ways in TESOL series II: Innovative classroom techniques.TESOL Quarterly.4(3), 222-228.

[33] Sindre, G. (2009). Experimental validation of the learning effect for a pedagogical game on computer fundamentals. Education, IEEE Transactions On, 52(1), 10-18.

[34] Sitzmann, T. (2011). A meta-analytic examination of the instructional effectiveness of computer-based simulation games. Personnel Psychology, 64, 489-528.

[35] Sylven, L. K., \& Sundqvist, P. (2012). Gaming as extramural English L2 learning and L2 proficiency among young learners. Cambridge University Press, 24 (3), 302-321.

[36] Tobias, S., \& Fletcher, J. D. (Eds.). (2011). Computer games and instruction. Charlotte, NC: Information Age Publishers.

[37] Yolageldili, G. (2011). Effectiveness of using games in teaching grammar to young learners. Online Submission, Elementary Education Online, 10 (1), 219-229.

[38] Wright, A., Betteridge, D., \& Buckby, M. (1984). 'Games for language learning' .Cambridge University Press. 

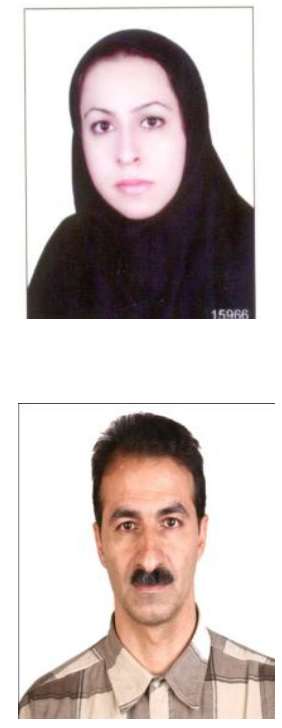

Marjan Sobhani is an M.A student majoring in Applied Linguistics. Currently, she is working as an English instructor. She accomplished her B.A from Islamic Azad University, Shiraz branch. Her main areas of interest are corrective feedback, writing, teaching methods and learning strategies.

Mohammad Sadegh Bagheri is an assistant professor teaching M.A. and $\mathrm{PhD}$ courses and working as the humanities faculty dean at Islamic Azad University, Shiraz Branch. He accomplished his M.A. and PhD in TEFL from Shiraz University and has some publications and articles on different issues. His main areas of interest are e-learning, motivation, learning strategies and international exams. 